\title{
ESSAYS
}

\section{LAW, COMMUNITY, AND COMMUNICATION $\dagger$}

\author{
Meir DAN-CoheN*
}

I follow the fashion of histing no inore, and no less, than three items in a title. If it weren't for this fashion, iny title would have included two more itenis-interpretation and organization. I shall relate these concepts in the following way: I shall pair coinınunity with interpretation and organization with communication. An important strand in contemporary legal and social theory-I have in nind primarily the work of Ronald Dworkin in this country and Jürgen Habermas in Europe-is fixated on the first couple consistnig of coinmunity and interpretation. In this it gives us only a partial representation of social reality and, specifically, of law; it paints only half, and as niy little daughter would say-the smaller half -of the picture. But drawing attention to the other elements in the picture, those I call organization and communication, does not simply suppleinent it. Rather, the fuller painting, I hope to show, bears scant resemblance to the partial rendering by Dworkin and others who belong in his niold. The linchpin that holds together the various terms I want to relate is yet another concept-role-distance-which I borrow, with soine modifications, from the work of the sociologist Erving Goffinan. ${ }^{1}$ Let me then start by describing this linchpin.

\section{Role-Distance, Community, AND ORganization}

The term "role-distance" belongs to the vocabulary of the self as well as to the vocabulary of social role, and serves as a bridge between the two. It is part of a drainaturgical imagery of the self, according to which the self consists, at least in part, of the social roles that it enacts. The special insight that the concept of role-distance inuports into this

\footnotetext{
Copyright by Meir Dan-Cohen

$\dagger$ This essay is a revised version of the Duke Law Journal Lecture, delivered in the Spring of 1989.

* Professor of Law, University of California, Berkeley, and Tel-Aviv University, Israel. I would like to thank Bruce Ackerman, Chaim Gans, Andrei Marmor and Leon Sheleff for their helpful comments, and the Editors of this review, especially Matthew Sawchak and Lorri Gudeman, for their friendly hospitality during my visit at Duke.

1. See Goffman, Role Distance, in Encounters: Two Studies in the Sociology of INTERACTION 83 (1961).
} 
picture relates to the self's capacity to locate itself, metaphorically speaking, at variable distances from the different roles that it occupies. Identification with a role is a matter of degree, and depending on the degree of identification, a given role may be more or less integrated with and constitutive of a particular self. This is the basic idea, and though my account of it must remain simplified, let me add a few further details.

Exactly what identification with a role or detachment from it consists of is a difficult matter, but the following criterion provides at least a proxy or approximation. When I fully identify with a role, when the role-distance, to further exploit the spatial metaphor, is down to zero, I enact the role "transparently"-i.e., without an explicit awareness of the role's requirements and the fact that I fulfill them. By contrast, the presence of role-distance is marked by self-consciousness: by an explicit awareness that $I$ engage im playacting; that $I$ enact a certain role by responding to its requirements and expectations.

Identification and detachment are not fixed properties of roles: The distance between a person and a role can shrink or expand, it can fluctuate over time. It is also not the case that some roles must be worn tightly, whereas others are kept at a distance by all their takers. I can become at times self-conscious about, and distanced from, every one of my roles, just as it seems that every role can in principle be enacted transparently by someone. Still a certain degree of uniformity in the style of enacting different roles exists, and so some generalization regarding roledistance is possible. Sone roles call for greater identification than others. Certain roles are in general more likely to be enacted at a distance than other roles. So it is ineamingful, though not altogether accurate, to speak in general terms about "detached" as opposed to "non-detached" roles. What I shall have to say depends, at any rate, on the soundness of this distinction.

Role-distance, as I said, is the linchpin that links the various concepts I want to relate. I will use role-distance first to distinguish two types of collectivity or social structure: community and organization. The juxtaposition is of course familiar. It immediately brings to mind Ferdinand Tö̈mies' distinction between Gemeinschaft and Gesellschaft, ${ }^{2}$ and I mean to capitalize on this association. But for my present purposes, I first want to draw the distimction exclusively in terins of the concept of role-distance. I will define a community as a social union of nondetached roles. Or, in other words, a community is a collectivity whose roles do not allow their holders to maintain a distance from those roles. By contrast, an organization is a social union of detached roles; or, it is a

2. See F. Tönnies, Community And Society (C. P. Loomis trans. 1957). 
collectivity whose roles allow or even call for distance. These definitions are admittedly stipulative, but they are not arbitrary. I would like to get at least your provisional assent to them, and $I$ hope to earn it by an illustration and an explanation.

Consider the role of a parent-a role within a collectivity, the family, which in its ideal form I take to be the paradigm of community. Contrast this role with that of say an AT\&T operator, who performs what I take to be a quintessentially organizational role. Let me now draw your attention to a few aspects of this opposition.

First notice that there are pretty clear social norms that regulate role-distance in these instances. To be a parent, characteristically, is to enact a non-detached role. Since there is no distance between me and my role as a father, since I fully identify with that role, the imperatives that guide me in discharging it are in an important sense internal to me. I simply do what I think best in a certain regard, e.g., in matters that pertain to my child's education, or behavior, or welfare.

We can say that in doing so my conduct as father is fully autonomous. This is not because I can treat my child with unfettered discretion, let alone arbitrarily. Quite the contrary. The demands of my role as father often are circumscribed quite narrowly, mandating a very specific attitude or course of action as the appropriate one. Still, these imperatives do not comproinise my autonomy but rather express it, since they follow from $m e$; they shape or constitute an aspect of my own identity, namely that of parent.

Nor should it be thought that my autonomy in going about my fatherly role depends on my doing so cheerfully and enthusiastically. Many a parent would flunk this test when getting up to attend to a screaming baby in the middle of the night, and yet their autonomy in performing the parental role is not thereby the least bit diminished. This conclusion derives, by close analogy, straight from Kant. The strain we feel in performing our moral duties-according to Kant-results from their frequent conflict with our inclinations. Still this is in an important sense an internal struggle, between different parts or aspects of the self. When we do follow morality, despite our inclinations, we act autonomously because we heed an internal, not an external, call. So also in the case of the parent. One's identification with the role, and one's autonomous execution of its demands, are not undercut but rather are put to the test by temptations and pressures that lead away from the role's requirements. Another way of making the same point, a way that also has clear Kantian overtones and will serve us later, is this: In enacting a nondetached role, my will is identical (within the role's domain) with the role's requirements. There is therefore no question of providing me with 
some "external" motivation to perform the various aspects of my parental role-e.g., to get up to my crying baby-since an "internal" motivation is already provided in the assumption that $I$ enact parenthood as a non-detached role. In that case I simply will the role's various inperatives, although my will on occasion may have to prevail over such impediments as my desire to go on sleeping.

Moreover, since there is no question of motivation to behave in accordance with the precepts of a non-detached role, there is a fortiori no question of coercion to do so. It is not that coercion is pragmatically unnecessary, but rather that it is conceptually out of place. Coercion becoines intelligible in this context only when the premises of my depiction of (the idealized) parental role already have been vitiated-i.e., when a gap has been opened between the person and his or her role as parent, so that comphance with the role's requirements is put into question for the first time.

A telephone operator's role contrasts with the parent's in all these respects. It would be utterly appropriate for the operator to keep the role at a distance. He can be an accomplished operator even though he just, as it were, goes through the motions of an operator (as long as, of course, he goes through them well enough). Since the operator need not identify with his role, its imperatives are external to liim. The main difference between the roles of parent and operator is not that the latter role's demands are more narrowly defined on any particular occasion than are the former's. The difference, mstead, lies in the source relative to the self of the guidance provided by the role. Insofar as the role that I enact is a detached one, I experience the role's imperatives as external, and thus potentially as constraints. "Potentially," because the role's requirements inay coincide, of course, in general or in any specific instance with my wants and desires. But this coincidence is, in principle, adventitious; it is not an essential part of iny relationship to a detached role.

It follows that unlike a non-detached role, a detaclied one presents starkly the probleins of motivation, autonomy, and coercion. Since I keep the role at a distance-outside of me-tlie role's requirements do not, in and of tliemselves, become my reasons or motivations for complying with them. The various tasks that compose the telephone operator's role, such as answering the numerous phone calls and operating the electronic switchboard, are not the things the operator himself lias any reason or desire to do. (The crucial point here is that it makes perfectly good sense to refer to the "operator himself," meaning the operator qua person, aside from this particular role. By contrast, it ordinarily would be clumsy to separate a person froin, say, the parent that he is.) If the operator is to perform his tasks, he must be inotivated soinehow-bribed 
or coerced-to do so. The most common combination used to this effect contaims elements of both kinds of inducement. Performing a detached role is therefore not, as such, a display of autonomy. I say "as such," because depending on a more detailed theory of autonomy, as well as on the nature of the second-order reasons one may have for enacting the detached role, its enactment may count as autonomous after all. But the individual's very engagement in the tasks of a telephone operator does not purport to express the operator's own will in the way that properly discharging parental duties is ordinarily supposed to be a manifestation of the parent's own will.

The telephone operator is a member of an organization-AT\&T in my example-simply in the sense, and by virtue of the fact, that he holds a detached role in that collectivity. For this reason, he in principle must be bribed or coerced if he is to perform the role's requirements. But don't those who do the bribing or coercing have to do so willfully, out of identification with their roles, and thus exemplify a communal type of participation in AT\&T? And, if so, isn't there a contradiction in describing AT\&T both as an organization and a community?

My answer to both these questions is negative. First, it is not necessary for anyone at AT\&T, including those who see to it that the operator perform his tasks, to identify with their roles. Putting aside the historical question of how AT\&T came to be, the organization presently can consist entirely of detached roles, all of which depend on some external source of motivation for implementation by their holders. Although it is not required that some of AT\&T's roles be non-detached, however, there would be no contradiction in terms of my proposed scheme if, in fact, some roles were to be enacted so. It is altogether possible for AT\&T to comprise some roles-upper echelon management, perhaps-that are to be held with no elbow room, with no personal distance. In my terminology, AT\&T would then provide a community for the holders of those roles, whereas it would continue to be an organization for its other role holders.

Why do some collectivities call for and some attain identification, whereas others engender or condone role-distance? Like other social questions, this one too can be investigated descriptively or normatively. And the normative investigation can be conventional in character-it can look for the source of various claims to role-identification or role-distance in a society's existing value system-or it can be critical, in the sense of trying to assess or ground such claims from the perspective of some ideal normative scheme. A complete theory of social structures in terms of variations in role-distance would have to tackle these various issues at the different levels, but that is not an enterprise in which I can 
engage here. Instead, I will settle for only some crude and speculative observations that will serve me in my present argument.

The mam hypothesis is this: There is a rough correlation in our society between role-distance-as both norm and reality-and a form of social organization that we can loosely call bureaucratic. Social entities fitting under this heading are marked by their large size, formal and hierarchical structure, and a relatively well- and narrowly-defined set of goals. It is primarily with regard to such entities-AT\&T is a paradigm example-thiat role-distance is engendered and condoned. We also can glimpse in passing an explanation-albeit a highly speculative one-for the prominence of role-distance im bureaucratic organizations. By isolating the self from the organizational role, role-distance shields the self to a degree from the blatant instrumentalism of these organizations. At the same time, role-distance gives those organizations as well as their members a certain flexibility and adaptablility that are likely to be conducive to the organization's operational success. Detaclied roles can be, if necessary, redefined or reassigned without thereby playing havoc with the selves of the roles' individual bearers.

If my lypothesis is sound, my characterization of community and organization in terms of role-distance will be roughly coextensive with our ordinary use of those two labels, based upon some general structural features that distinguish the two types of collectivity. My proposed characterization, however, lays emphasis on what, at least for my present purposes, deserves the greatest attention: The radically different relationship to the self that various collectivities can and ought to bear.

One final observation: Role-distance is a normative as well as descriptive concept. One's appropriate distance from various roles is regulated normatively and, as I said, is amenable to assessnient on both conventional and ideal grounds. In all of this, role-distance must be sharply distinguished from alienation, which is a nalady of the self. In the conceptual scheme that I propose, alienation is an inappropriate roledistance-i.e., it is distance from what is supposed to be one's communal role. So understood, alienation contrasts with what would be the self's opposite disease: misplaced identification with what ouglit to be a distanced, organizational role. The name of this disease is bad faith. ${ }^{3}$

\section{INTERPRETATION AND COMMUNICATION}

I turn now to the second pair of concepts that I want to juxtapose: interpretation and communication. I begin with a caveat: The way in

3. This expression is borrowed from Sartre. See J.P. SARTRE, L'ETRE ET LE NEANT 82 (1943). 
which I'm going to use these terms may well create confusion, and I shall try to avoid it by the following clarifications. I borrow the notion of interpretation directly from Ronald Dworkin's writings, primarily his book Law's Empire, ${ }^{4}$ where this concept is already shaped to suit our legal concerns as the centerpiece of a theory that Dworkin calls "law as interpretation."'5 However, it seems to me we can better understand Dworkin's conception of interpretation, as well as appreciate its shortcomings, if we view it in the light of an important distinction drawn by Jürgen Habermas in his theory of communicative action. ${ }^{6}$ Habermas sharply distinguishes between two kinds of discursive social action: "communicative action" and "strategic communication." In coinmunicative action, the participants are oriented toward reaching agreement through understanding. In strategic coinununication, by contrast, participants are oriented toward success; they have a specific goal determined antecedently to their discursive behavior that the latter is designed to promote. My clain is that Habermas' notion of coinmunicative action-i.e., discourse oriented toward agreement through understanding -is closely related to Dworkin's idea of interpretation. ${ }^{7}$ I shall not be able to defend fully this claim here-though I trust that it does not seem particularly controversial to those familiar with the relevant writings. At any rate, I shall have to rest my case mainly on one central factor common to both notions. The engine that drives Dworkin's interpretation as well as Habermas' coininunicative action, or to shift the metaphor, the beacon that attracts them both, is truth, or perhaps more accurately, a shared belief in its attainability. I propose to treat interpretation and cominunicative action as one pole, which I shall call-following Dworkin's usage-interpretation, of an opposition that has the notion of strategic communication, or simply communication, as the other pole.

The terms interpretation and communication are convenient labels for the polarity that I want to describe, but as I warned already, and for reasons that I hope are now soinewhat clearer, my use of these terms is potentially misleading. Both terms, interpretation and communication, are characterizations of discourse, and thus both pertain to communication. My derivation of the notion of interpretation in part from Habermas' concept of "cominunicative action" underscores this obvious fact. Still, my proposed usage-juxtaposing interpretation with commu-

4. R. DWORKIN, LAw's EMPIRE (1986).

5. See Law as Interpretation, in The Politics of INTERPRETATION 287 (W.J.T. Mitchel ed. 1983).

6. See J. Habermas, Communication and the Evolution of Society ch. 1 (T. McCarthy Trans. 1979) and J. HABERMAS, THE THEORY of COMMUNICATIVE ACTION ch. III (T. McCarthy trans. 1981).

7. See R. DWorkin, TAKING Rights Seriously ch. 4 (1977); LAW's EmPIRE, supra note 4. 
nication-has a substantive justification in addition to its convenience. It helps bring out the internal relationship between interpretation and coinmunity that I have anticipated at the outset. My point is this: Though the program of interpretation does characteristically involve a plurality of participants, it is evident in both Dworkin's and Habermas' depiction of it that the existence of a plurality is not essential to the proper analysis and understanding of imterpretation under ideal conditions. This is so for the following reason. Those ideal conditions, which, as Professor Dworkin is at pains to emphasize, point to the fact that imterpretation takes place in the context of coinmunity, secure a degree of cognitive ahignment and motivational coordination annong the participants so as to make their plurahity insignificant. As embodied in Dworkin's famous allegory of Judge Hercules, interpretation in principle can be understood successfully on a monological model, as though the discourse under consideration took place within an individual's internal forum in which the interlocutors are all figments of the interpreter's own imagination. ${ }^{8}$ In deploying competing views and arguments, these imaginary speakers serve a purely heuristic purpose in the unified search for truth and understanding. 9

In terms of the role-distance metaphor and the idea of community to which it gives rise, the picture is this: When individuals fully participate in community, when they efface all distance between themselves and their coinmunal roles, then the system of interlocking roles, which is the community, constitutes a configuration of partially intermingled personal identities. "Partially," because the individual identities intermingle only along the dimension or within the domain that defines and bounds the particular coinmunity that these individuals share. But insofar as matters concerning the community go, the members occupy a common space, which is fully continuous with each member's private space. We plausibly can imagine their public discourse as taking place within a

8. Cf. Michelman, The Supreme Court, 1985 Term-Foreword: Traces of Self-Government, 100 HaRv. L. Rev. 4, 73 (1986) ("The judge, as Dworkin envisions him, represents . . . by his own practical reason our missing dialogue.").

9. The ease with Habermas is more complicated. His advocacy of and contribution to a "formal-pragmatic" approach to a theory of meaning is presented by him in part as a reaction against the monological conception characteristic of "formal-semantics." He draws in this context on the "intuitively accessible distinction between thinking in propositions in abstraction from speaker-hearer relations and imagining interpersonal relations." J. HABERMAS, THE THEORY OF COMMUNICATIVE ACrion, supra note 6, at 440-41. However the dialogical component that Habermas deems essential for the understanding of communicative action is on his view consistent with and is satisfied by the imaginative assumption by the solitary thinker of "the roles of proponent and opponent as a communicative relation in his thought." Id. This description comports with my characterization in the text of the essentially monological nature of interpretation. But the issue (regarding Habermas' position) is difficult, and I cannot do it full justice here. 
single member's private forum precisely because the relevant zone of that private forum is continuous with the community's public space.

This, I believe, is the picture that underlies and best explains the concept of interpretation as articulated by Dworkin and Habermas. This picture links up with a number of important features of interpretation that I shall now consider.

Recall the examples of parent and telephone operator that I used earlier. Dworkin derives his description of law as interpretation from an analysis of interpretation in the context of another social practice: courtesy. ${ }^{10}$ In order to keep the following comments as parallel as I can to Dworkin's discussion, I shall also begin by placing my protagonists, the parent first, in a similar context. Suppose that someone had just helped my four year-old daughter to cross the street, as I happen to walk by. Being in general a polite fellow, I wonder (this of course is just a way of speaking) whether courtesy makes any demands on me in these circumstances. The answer is plain, and so I say to the benefactor something like, "Thank you for lielping my daughter." The first thing to notice about this situation is this: My expression of gratitude is strictly a matter of performing my role as father. After all, the benefactor lias not rendered any help directly to me. It is only by virtue of my parental role, and as an aspect of it, that it is appropriate and necessary that I thank the lielper under these circumstances. But it is equally inportant to notice that once $I$ have ascertained that it is incumbent upon a father to express gratitude under these circumstances, no further question about motivation-i.e., why did $I$ express gratitude-arises. This motivation is already provided for (though it is not invariably guaranteed) by my general tendency to excel at what I take myself to be-by my striving to be the best at what I am. In this case, my general tendency to be a polite person is sufficient to secure my performance of such a speech act, because my being a father is simply the aspect of my personal identity that pertains to the situation at hand.

Suppose now that the above episode happens when I'm in my wife's company. As we're approaching the helping person, my wife urges me to thank the stranger for her lielp. I demur: "It was none of this woman's business to help our daugliter go where we didn't want her to go," I argue. It is now open to my wife to persuade me that I have taken the wrong attitude; that gratitude and its expression are due. I may be persuaded by her reasons, or I may defer to her judgment, which, in matters of courtesy, I consider superior to mine. All of this possible interaction comports with the spirit of community and counts as an exercise in inter-

10. See R. Dworkin, LAw's EmpIRE, supra note 4, at 46-49. 
pretation. A good test of this conclusion is whether I can imagine the saine dialogue occurring "m my head," with me deploying my wife's arguments on her behalf and then duly considering them. There is however one thing that my wife decidedly cannot do and still remain within the interpretive enterprise. She cannot, when all fails, squeeze my elbow and mutter through clenched teeth: "Thank her or I'll break your arm!" As Haberinas insists, interpretation proceeds on the participants' shared assumption of their mutual desire to reach the truth, to the discovery of which they all have an equal clain. Understanding, both in the sense of improved comprehension and increasing agreement, is the exclusive concern of this form of discursive activity. Forcing assent by coercive measures cannot promote imterpretation; it can only undercut it and convert it into a form of the antinomous category-strategic communication. Observe also that resort to coercion suspends community. If I act on my wife's threat and thank my child's benefactor for that reason, I act apart from, and despite, my own understanding of my role as father. I am propelled by external inotivation, with whose source I do not identify. By issuing the threat, my wife herself has stepped out of our shared communal space and has, instead, installed herself as the final arbiter of an enterprise that I am, at that moment, no longer expected to share.

Let us return now to the original version of my story to observe another aspect of my thanking my daughter's benefactor. An important aspect or consequence of the fact that I identify with my fatherly role, is that by making the appropriate utterance-" "Thank you for helping my daughter"-I express my gratitude. In doing so, I abide by what speech act theorists refer to as the condition of sincerity, which im this case simply means that iny utterance truthfully conveys my sense of gratitude. I'll have more to say later about the significance of this observation.

Now contrast the episode above with another familiar display of politeness. Recall our second protagonist, the AT\&T operator. If courtesy were measured by the frequency with which one utters words of politeness, that operator would surely be a world champion in the field. As anyone who has ever needed his or her assistance knows, the operator concludes each exchange, no matter how short or trivial (and these exchanges tend to be both) by proclaiming: "Thank you for using AT\&T." Now, on the face of it, this utterance is on all fours with my "thank you for helping my daughter," addressed to her benefactor. Still, the differences are striking. We can mark them by looking again at the elements of inotivation, coercion, and sincerity that we have considered before.

The point about motivation can perhaps best be made by noticing that, unlike the case of the grateful father, the operator's recitation of thanks bears no relationship to a personal disposition towards politeness 
or its absence. This feature of the situation follows from, and testifies to, the fact that the politeness evinced by the operator remains external to him. Both in the case of the parent and the operator, the relevant script is written into their respective roles. But, unlike the parent's role, the operator's role, including the particular script we consider, remains at a distance. The fact that the role of operator mandates an expression of gratitude, on certam specified occasions, has in itself no hold over the role-player. There must be some other source of motivation to compel his utterance of the required text. Such motivation can be provided for, consistent with the organizational nature of the role, in the form of either bribery or coercion. A recalcitrant operator surely will be threatened with dismissal if he fails to perform the incantation, irrespective of the earnestness of his belief that the required practice is silly and inappropriate for him, or the role he holds. Or imagine the operators going on partial strike, their union decreeing: "No more of this 'thank you' silliness until we get a raise." It would seem altogether appropriate for AT\&T to meet the union's demands by actually paying the operators to perform that particular aspect of their task. Moreover, as our example clearly demonstrates, the point of the organizational speech act is essentially instrumental and therefore strategic. On the prevailing understanding of corporate legitimacy, the avowed point of the operator's polite refrain must not be the expression of gratitude, but rather the business purpose of trying to secure customers' continued patronage of the firm.

Finally, observe that the norm of sincerity does not belong in this language game. Professor John Searle, a leading speech act theorist, supports the claim that the requirement of sincerity is a condition for the successful performance of a speech act, by observing that "it is linguistically unacceptable (though not self-contradictory) to conjoin the explicitly performative verb with the denial of the expressed psychological state."11 One cannot well say, "thank you, but I'm not really grateful." However in the operator's case, we can find an opposite and equally instructive oddity. It would be quite ludicrous for the overly zealous telephone operator to say "thank you for using AT\&T," and then add: "And I really mean it." The oddity would not be removed even if the particular operator happened, in fact, to experience a sense of gratitude, born of either misplaced identification with AT\&T or a belief that his own livelihood is secured by the customer's patronage. The conclusion that the norm of sincerity does not apply in this context is both a product, and evidence, of an organizational setting marked by role-distance

11. J. Searle, Expression ANd MEANing 4-5 (1979). 
and discourse that is essentially communicative-i.e., to use Habermas' description, oriented toward success and strategic in nature.

I hope I have said enough to give at least a rough idea of how variations in role-distance give rise to two kinds of social collectivity-comnunity and organization-and, respectively, to two forms of discourse: truth seeking, understandinig-oriented interpretation and strategic, success-oriented communication. It is now time to place law in this franiework.

\section{Legal Roles and Legal Discourse,}

In this short space, we shall not be able to derive fron the framework I have proposed all the answers concerning law that it potentially might yield; but we can get a head start by first using this framework to help us formulate some questions about law. The suggested framework permits us to pose in three different and, I thimk, mutually illummating ways what is essentially the same question. Do the various legal actors perform their respective roles in a detached or non-detached fashion? Does law take place in the context of community or organization? And finally, is legal discourse an exercise in interpretation or communication? The general answer to each one of these questions (or more precisely to the three formulations of the one question) seems to me to be plainly, both. If, however, I were pressed to choose, I believe that the concepts of role-distance, organization, and communication are more central to law than the opposing terms. Here are some considerations that support, as well as clarify, this hypothesis.

\section{A. Lawyers}

Much of contemporary jurisprudence, notably Dworkin's, revolves around adjudication. Thus, the courtroom will be a natural place for us to begin the legal part of our journey. But whereas Dworkin and others preoccupy theniselves with the role of a judge, I propose a provisional shift of focus: I suggest that we direct our spotlight first on the lawyers. Although the judge has the final word in the courtroon, it is the lawyers who do most of the talking. As we investigate legal discourse, the lawyers deserve more of our attention: How are we to characterize and understand their role and their discourse?

We can get a clue by recalling the problenı we just raised when we put the AT\&T operator's thanks to the test of sincerity. Analogously, try to imagine a lawyer presenting a compelling legal argument, only to be greeted at the end of his speech with the judicial question: "Very persuasive, but do you really believe what you've just said?" A judge, 
probing into the lawyer's sincerity, would be breaching some of the fundamental rules of the game. The point here, as in the operator's case, is not that the one protagonist or the other-the operator or the lawyermight lack the psychological state that his or her speech act ostensibly expresses. This fact, in itself, would be utterly inconsequential. The point is that in both situations the norm of sincerity does not at all apply. This conclusion accounts for the indisputable oddity, in both cases, of inquiring about or affirming the psychological state that other speakers, using the same language under different circumstances, would be expected to possess. This is not to say, of course, that the lawyer can get away in court with absolutely any argument; there are limits to what the lawyer is allowed to say; limits that shape and restrict his or her speech. But sincerity has nothing to do with these himits. The condition of adequacy of a lawyer's speech act is not a pure heart, but only a straight face.

Lawyers routinely say, and indeed are expected to say, things they are not supposed to believe. Are they therefore irredeemable liars or dissemblers? Perhaps so. But their ultimate salvation, if there is to be any, lies in role-distance. When arguing before a court, the lawyer typically performs a highly detached role. As with the telephone operator, the lawyer's role involves a script (or rather, in this case, a range of scripts), which the lawyer is motivated to utter simply by being paid to do so. We must further investigate the shape and the point of this arrangernent. But we can already observe that it is only a picture such as this that can take lawyers off the moral hook and preserve their rectitude by maintaining a space-visible and generally recognized-between their person and their role, and thus between their beliefs and their utterances. ${ }^{12}$

What is the point of a role that systematically engages its holders in the performance of insincere speech acts? There is a conventional answer to this query: We should not consider a single lawyer's speech in isolation, but rather we should view it as part of a process. And the process, unlike its component parts viewed separately, is designed to attain legal truth. By pitting one-sided lawyers against each other, the process assures that each side of the coin is painted meticulously for the judge to inspect and make the right decision.

12. My view of the lawyer's role is accordingly antithetical to the one suggested by Professor Charles Fried in The Lawyer as Friend: The Moral Foundations of the Lawyer-Client Relation, 85 YALE L.J. 1060 (1976) (arguing that an attorney is a legal friend who makes his client's interests his own in so far as necessary to preserve the client's autonomy within the law). I side instead with Fried's critics, according to whom, "Most lawyers are free-lance bureaucrats." Dauer and Leff, The Lawyer as Friend 86 YALE L.J. 573, 581 (1977) (Reply to Professor Fried). 
The premise that underlies this conventional account-that legal truth will best emerge out of the opposition between two dehiberate efforts to distort it-raises, of course, many difficult problems. ${ }^{13}$ But I shall not challenge this premise here. Instead, I want to suggest that even if we grant its validity, grounds remain for dissatisfaction with the account of litigation that rests on it. First, this account assigns to the lawyer a function that is best understood as a "latent function": one that ought to be hidden from the lawyer himself. On the premise we granted, truth is best served when each lawyer acts $a$ if if he or she were devoted to his or her chent's cause. But if the lawyer took seriously the notion that all this is done only in the service of his real function-to attain the truth-he might be tempted, consciously or unconsciously, to cheat against his assigned role by himself glimpsing the truth and smuggling it into his presentation, thereby undermining the process that his onesidedness is supposed to serve. The acceptance of the proposed account of a lawyer's role by the lawyers themselves accordingly would be selfdefeating. Evidence abounds that lawyers, in fact, do not construe their role in light of the conventional account. Which lawyer, for example, would ever celebrate his or her latest defeat in court by toasting the victory of truth?

The second madequacy of the proposed account is that it explains only some, but not all, of the prominent features of lawyers' discourse. Even if presenting one-sided arguments can be thought plausibly to promote truth, it is much more difficult to maintain such optimism with regard to other aspects of the lawyer's performance. I have in mind practices such as "courtroom tactics" or "litigation strategies." These terms do not, after all, describe some devious practices of shady lawyering; they are part and parcel of the prevailing conception of a lawyer's role, and they can feature unabashedly in any law school's curriculum.

We need an account of the lawyer's role that encompasses these additional features and serves, without self-destruction, the lawyers themselves in the construal of their task. Such an account is, of course, readily available. It is simply that the lawyer's role is designed to help his or her client win a lawsuit. Insofar as litigation is concerned, this is the lawyer's primary function; occasional lame references to the lawyer as an "officer of the court" can neither mask nor change this overwhelming reality. ${ }^{14}$ We must dwell longer on such characterization of the lawyer's role, but we can first draw out its implications for the kind of

13. Such problems are discussed, for example, in J. Frank, CourTs on Trial: MYTH AND REALITY IN AMERICAN JUSTICE ch. VI (1949).

14. Cf. M. DamăsKa, The Faces of Justice and State Authority: A Comparative APPROACH TO THE LEgAL PROCESS 143 (1986) ("The invocation of counsel as officer of the court is 
discourse in which lawyers engage. Their discourse is a paradigmatic case of strategic, success-oriented communication. It is geared toward the attainment of a preconceived goal-that is, a favorable outcome for one's client. In speaking, the lawyer is acutely aware of the identity of his or her audience-the judge or the jury. The latter's disposition and attitude, inasmuch as he can ascertain thein, strategically guide both the style and the content of the lawyer's speech.15

The account of lawyering that I have just outhined is so obvious that we may fail to be puzzled by it, but it is important for my argument that we are. However, our perceptions and beliefs in this area are sufficiently mixed that it should not be difficult, I hope, to provoke the requisite puzzlement. Think of it this way: Here is the judge heroically laboring at the altar of truth, while being constantly diverted by two characters who view it as their legitimate purpose to deflect her, each one trying to sway the judge in his preferred direction. The same incongruity can be stated in different terins. The judge, we are told, engages in an Herculean effort at interpretation. She is trying to divine the right answer to the legal problem by (ideally) constructing a comprehensive theory of law that would best fit the extant legal inaterials and present them in the most attractive moral light. But the other discussants, froin whom she seeks assistance and illumination, instead of joiming the interpretive effort, overtly adopt a communicative mode and, by using various discursive tactics and strategies, they try to extract a favorable result from the judge.

This dissonant mixture of discursive styles is no doubt puzzling, but we can start toward a solution by observing how far removed the circumstances of a trial are from conditions that, according to Haberinas, ought to characterize truly interpretive discourse. The participants in the latter

designed to constrain the excessive amalgamation of the lawyer's interest with that of his client and to forestall the transformation of privately managed litigation into a melee of self-seeking.").

15. This characterization of lawyers' speech should be distinguished from a related one proposed by Joseph Raz. The latter is based on his distinction between 'committed' and 'detached' normative statements. Committed statements are made by those who accept the validity of a normative system. Detached statements do not imply such acceptance: the speaker makes them from the point of view of someone who accepts the system's validity, without being himself so committed. According to Professor Raz, the lawyer advising her client is a good example of such detached, noncommitted speech. But notice that detached speech can still be sincere: In the usual case, the lawyer would be expected to convey to her client her sincere view of the legal situation (whether or not she also accepts it as sound or authoritative). By contrast, the strategic communication that I ascribe to the lawyer in court is 'detached' in a stronger sense, in that it is exempt from the norm of sincerity altogether. See J. RAz, Practical Reason AND Norms 170-77 (1975), and The Authority OF LAW: ESSAYS ON LAW AND MORALITY 153-77 (1979). As Raz points out, the distinction is present, albeit in a less crystallized form, in Kelsen's writings. The description of Raz's distinction in the language of committed vs. detached statements is introduced in H.L.A. HART, Legal Duty and Obligation, in EsSAYS ON BENThaM: JuRISPRudenCE AND Political TheORY 127, 153-55 (1982). 
enterprise each have an equal claim to interpretive truth. They are motivated to reach common understanding, and their mutual accommodation is free from coercion. But this picture is a poor model for the trial in which, at the end of the day, the judge's interpretive conclusion will prevail, even in the face of lingering disagreement, as a result of the superiority not of reason but of brute force. Faced with the prospect of an unwelcome (and perhaps unwarranted) interpretation forced on them by the judge, the litigants' response is not surprising. They resort to an expert in strategic communication - a lawyer-to make right the discursive imbalance and to reduce the likelihood that coercive measures will be visited upon them.

So far, we have answered two of the three questions posed with regard to the lawyer's role: We have characterized it as a detached role and the lawyer's speech as a species of communication. The remaining task is to identify and characterize the collectivity within which the lawyer's role is defined and im relationship to which this role is enacted. The answer is evident: The lawyer's role is defined by and is a constituent of the municipal legal system and, as such, this role belongs, as does the legal system itself, to the state. We should not be misled by the fact that a lawyer typically is not an employee of the state and is not, in this sense, a public official. Nothing of importance for our purposes hangs on this formality, as is evidenced by the fact that nothing in our understanding of the lawyer's role changes on those occasions-think of the prosecutor or the public defender-in which the lawyer is a state employee. Whether on the government's payroll or not, the lawyer is, if you like, an official of the legal system and, in this important sense, his role belongs to the collectivity whose legal systems it is, namely to the state. The point is worth stressing because it provides a crucial link to the following conclusion. Seen from the perspective of the lawyer's role, the state is, in my proposed definition, an organization, that is, a union of detached roles. The relationships that it defines among its nembers (I am still talking only about lawyers in court) are external relationships-mediated but also separated by the visible gaps between the selves involved-between people in their "personal" capacity, on the one hand, and the clusters of tasks, duties, and expectations (discursive or otherwise) which make up those people's detached roles, on the other. It is in its capacity as an organization that we can best understand the state cultivating a breed of speakers who are exempt from the norm of sincerity and one of whose tasks consists in the use of communicative strategies to defend individuals against the state's own coercive power.

A further question that naturally arises-why should the state uphold such an arrangement-would take us further afield into political 
theory than we can now venture. I only want to remove the air of paradox from what looks like a self-defeating interpretation of the lawyer's role from the state's perspective. In principle, there is nothing paradoxical about observing different roles in an organization working at, what looks like, cross purposes. This might mean only that the organization's purpose is more coinplex tlian we initially tlought, or that the organization does indeed serve conflicting purposes, such that the interactions among conflicting roles are the way the organization reaches a compromise or an accominodation.

We have been dealing so far exclusively with the lawyer's role, and it was only in regard to this role tliat we considered the state as an organization. But we now can expand our vision, and observe the state in a more cinemascopic fashion, unrestricted by any particular role that it assigns. In terms of our two-fold classification, what sort of entity is it? The case for classifying the state as an organization looks overwhelming. ${ }^{16}$ We cannot fully examine this case here, but it will suffice if I mention two prominent features of the state that strongly argue in favor of this classification: bureaucracy and coercion. We often think of the state as a vast bureaucracy or, perhaps more accurately, as a conglomerate of bureaucracies-all impersonal, goal-oriented, self-perpetuating organizations. As I liave said before, such entities inspire distance, and we tend to experience our interactions with them, in whatever role or capacity, as remote and external. The state is also the quintessential coercive collectivity. It often addresses us by means of threats, backed by the most brutal force. Reliance on such external motivation for compliance with the state's demands both fosters and reflects distance. It is at once a recognition and a consolidation of the fact tliat one's actual continued assent is not required or expected as a condition of one's playing a role in a collective enterprise. When we contemplate the state under both of these aspects-bureaucracy and coercion-we think of an organization, of a collectivity whose claims are external to us and from whose clutches we flee by maintaining a distance between our engagements with it, on the one hand, and our true selves, on the otlier. ${ }^{17}$

These aspects are, of course, not the only aspects under which the state can be contemplated. The state is not just bureaucracy and coercion. To be an American, for example, is not only to stand in a certain

16. For an exploration of some legal-theoretical implications of applying to the state an organizational perspective, see M. DAN-Cohen, Rights, Persons, and Organizations: A LEgal THEORY FOR BUREAUCRATIC SOCIETY 163-98 (1986).

17. For a similar conception of the state and its relation to the self see Gabel, The Phenomenology of Rights-Consciousness and the Pact of the Withdrawn Selves, 62 TEx. L. REv. 1563, 1563 (1984). 
relationship to the American government and to be subject to its coercive threats. It also means to share important bonds of language, culture, history, and morality with a vast number of other people. "American" is accordingly a summary reference to a composite role or perhaps even more accurately, a cluster of roles, many of which are non-detached, mextricable constituents of an American's innermost identity. The state is therefore also the social umion of these non-detacled roles and, to that extent, a community.

But the organizational aspects of the state cannot be ignored. These aspects of the state enjoy special relevance in connection to law. Law characteristically provides the context or the medium within whicl we encounter the state as government, that is to say, in its bureaucratic and coercive capacities. ${ }^{18}$

\section{B. Judges}

With these observations we can now move to what will be the last stage of our inquiry: a consideration of the judicial role. We slall again proceed in terms of the three questions we posed before, trymg to cliaracterize in terms of our dichotonnes the kind of role, discourse, and collectivity that pertain to judging.

I have just summarized a case for the communal conception of the state, and it is along these limes that Dworkin's theory of adjudication, and of law, gains whatever plausibility it has. The judge is rooted in a common culture and a shared morality, and is the exponent of an evolving tradition. Slie is, in Professor Owen Fiss' idion, ${ }^{19}$ the articulator of our (that is the community's) public values. She engages in what is a quintessentially interpretive venture, of which Dworkin's analysis is as good as we have ever had: The judge tries to express in her decision the best vision of the community's tradition that slie can divme. In doing so, there is no space, as Professor Stanley Fish is riglit to msist, ${ }^{20}$ between the judge's personal and judicial views on the matter. And there is no space, because her judicial views are her personal views, just as bemg a judge is being simply who sle is at the relevant time and with regard to the relevant issues. Seen in this higlt, the judge's interpretive utterances are inarked by sincerity: They convey her genuine vision, conditioned but not separated by her role, of the proper disposition of the case, sup-

18. There is of course considerable literature warning against the fallacy and the danger of conceiving of the state in excessively communal terms. A well-known example is R. NiSBET, THE QUEST FOR COMMUN1TY (1953).

19. See Fiss, The Supreme Court, 1978 Term-Foreword: The Forms of Justice, 93 HARV. L. REv. 1 (1979).

20. See Fish, Still Wrong After All These Years, 6 LAw AND PHIL. 401, 412 (1987). 
ported by what she takes to be the best arguments and the right principles.

This is an ennobling, almost beatific, picture of the judicial role, and it is valid as far as it goes. But it does not go very far. It starts to come apart as soon as the judge looks down from these interpretive heights at the litigants and recalls the bearing that the conclusions she reaches will have on them. The judge must then realize that in the litigants' ears, her interpretive pronouncements are liable to be converted into hard-edged commumication, as they come down not just clotlied in the state's authority, but also backed by its superior physical force. That is an essential part of the legal context-the acceptance of the judge's position by the litigants is not conditional upon their reaching an agreement on the merits of her position, an agreement discursively worked out through the free flow of unconstramed, truth-oriented speech. On the contrary, the parties' assent is ultimately secured through brute force. We have already observed the implications of this all-important fact for the lawyer's role. But this fact is significant in shaping the judge's role as well. Even if the judge sets out to perform a feat of Dworkinian interpretation in the context of community, she then must convey her interpretive conclusions to the litigants. And in doing so, she must shift, as we have just observed, into an altogether different discursive mode. The judge presents the litigants witls a non-debatable proposition; the ultimate purpose of the judge's utterances is to secure compliance, not to generate agreement; and her speech act is accompanied by a threat of force. In short, we have here the makings of strategic communication that stands in sharp contrast to the interpretive soliloquy in which the judge may have engaged before.

We have now come up with a composite, two-stage depiction of judicial discourse. First, the judge engages in Dworkinian interpretation in which, as you remember, she is instructed to scan all relevant legal texts and construct a theory that fits them best, while presenting them in the most attractive moral light. Having reached in this way a conclusion that slie believes to be right, the judge then faces the additional task of writing an opinion-i.e., addressing the parties in a way designed to secure their compliance with the results of the interpretive exploration.

But a moment's reflection will reveal that this two-stage process, with its promise of peaceful coexistence between interpretation and communication in the judicial role, is highly problematic. It faces an obvious difficulty: If the actual judicial pronouncements-the judicial opinionsare crafted strategically, with an eye to communicative exigencies, then it makes no sense to take these same opinions at face value as the texts that ought to guide and to ground the interpretive efforts during the first 
stage. Once we allow communicative concerns to enter into judicial speech, we cannot inaintain the interpretive stage intact. When legal niaterial beconies infected with strategic, success-oriented considerations, it no longer can plausibly be held up as the repository of the coininunity's accurnnulated wisdoin and ideals. The text was designed with a inotive ulterior to that of discovering the truth and conveying it so as to promote understanding and foster agreeinent. Now as a truth seeking interpreter, I must somehow see through the rhetorical devices and the strategic intentions. Using the judicial text as rendered as the object of my interpretation is bound to lead ine astray.

I have focused so far on the relation in which the judge stands to the parties, but the communicative exigencies of his role do not stop here. In articulating our public values, to use again Fiss' phrase, judges do not view themselves, nor are they viewed by others, as contributing to the public's enlighteninent along lines essentially similar to, say, moral philosophers or legal scholars. The judge's proffered articulations do not engage $\mathrm{n} 1$ discursive conipetition with the other sources, and his clain to interpretive superiority is not put to the test of general assent. A judicial pronouncement is presented as unconditionally valid; it must be followed whether or not we concede its truth or accept its authority. In either case, it is backed up by the state's force, ready to descend on those who resist the judicial interpretation and would opt for a different articulation.

The fact that the state's power underwrites the judge's pronouncements reveals their true discursive point. Judicial utterances are supposed to secure certain forms of conduct, not only to highlight or recoininend their desirability. These utterances are therefore successrather than truth-oriented; they are communicative rather than interpretive. And, given the coercive background against which a judicial speech is uttered, the more successful it is in inducing coniphance, the less need there may be to resort to the coercive measures that back it up.

The judge's coinmunicative task is not a simple one, and we cannot hope to do justice to its conplexities in the present essay. Let me just inention very briefly two of the difficulties with which judicial communication must cope: One is the multiplicity of audiences and the other is the variability of contexts. In the case of interpretive discourse, these issues do not arise. As you recall, I said earlier that interpretive activity can be understood in essentially monological terms: No special attention need be paid to the audience and the context. The speaker shares a coinmon context with the hearer and tacitly assumes the hearer to have the same linguistic and cognitive dispositions as his own. Thus, context and audience recede into the background and are taken for granted. By con- 
trast, the judge can take neither audience nor context for granted. First, to make her pronouncement stick, the judge must consider the possibility that she addresses a multiphicity of audiences, whose responses to a given utterance might vary considerably. I have no space to explore this issue any further here; all I can do is drop a footnote to Professor Sadurski's helpful illustrations of what he calls the "strategy of reassurance" in which the Supreme Court engages when it affirms in general terms a dommant moral view while actually deciding the case in accordance with a more controversial moral position. ${ }^{21}$ The Court here is playing to different audiences, so to speak, and its rhetoric involves a difficult balancing act that tries to respond to their contrasting dispositions and expectations.

Variability of context is a problem that results primarily from the temporal dimension of judicial opimions: The judge projects her vision into an indefinite future and thus must intend it to exert its force under changing circumstances. If her vision is to command compliance in the long run, the judge must be sensitive to the contextual shifts under which her opimion will necessarily operate. Agam here I can do no more than give an illustrative reference, this time to Professor Blasi's view of First Amendment doctrine-as designed with times of political emergency in the judge's mind ${ }^{22}$-and to the illuminating exchange between Blasi and Professor Christie about the role of strategic considerations of this kind in judicial opinions. ${ }^{23}$

Characterizing judicial speech as communicative provides the answer to one of the three questions concerning the judicial role that we have posed. Let me now turn to a brief consideration of the other two. The judge's utterances, I have observed, are presented to us as non-optional, non-negotiable propositions; from the outset they are assured victory in the competition for legal truth. But why do judges claim infallibility, which they do not in fact possess and which is backed by force they do not fully control? The only satisfactory answer I can see is that they do not. Or, perhaps more cautiously, that they ought not. So if

21. Sadurski, It All Comes Out in the End: Judicial Rhetoric and the Strategy of Reassurance, 7 OXFORD J. LEG. STUD. 258 (1987).

22. See Blasi, The Pathological Perspective and the First Amendment, 85 Colum. L. Rev. 449 (1985) (arguing that courts should interpret the first amendment to provide maximum protection when intolerance of unorthodox ideas is prevalent and government is likely to stifle dissent).

23. See Christie, Why the First Amendment Should Not Be Interpreted From the Pathological Perspective: A Response to Professor Blasi, 1986 DUKE L.J. 683 (advocating that judges should consider legal argument, rather than a theory of societal good, in deciding cases); Blasi, The Role of Strategic Reasoning in Constitutional Interpretation: In Defense of the Pathological Perspective, 1986 DUKE L.J. 696 (advocating the use of strategic reasoning to safeguard "core" constitutional commitments in first amendment cases). 
some do, they suffer from a massive case of bad faith. As with the lawyer's escape from the charge of dissembling, the judge's defense from what otherwise would be spectacular hubris hes also im role-distance. An implicit claim to infallibility is written into the judicial role, but it does not attach to the judge qua person. In other words, we-this mcludes judges as well-must at all times be aware of the difference between the judge in his or her personal and official capacities. The rather sharp line between the two can be erased and the distance between them eliminated, only at the cost of the judge ascribing to hin or herself awesome, and rather grotesque, omnipotence and ommiscience.

Insofar as the judge's is a distant role, to that extent his is also an organizational rather than a communal function. This conclusion is not surprising. It is eminently consistent with the bureaucratic and coercive aspects of the state that are inextricably connected with the judicial role. It is an avowed purpose of this social structure to secure order and promote cooperation, if need be by force, in the face of recalcitrance, moral diversity, and disagreement. This is an agenda far removed from the spirit of coinmunity and fraternity that underlies and motivates Dworkin's theory of law. And it is in relation to this agenda that the judicial role must be nnderstood.24

\section{CONCLUSION}

I cannot examme here other legal role players, most importantly citizens in their capacity as litigants and in other capacities, and I shall end with the two following observations. First, by describing judging, as well as lawyering, in ternis of role-distance, strategic communication, and organization, I do not mean to deny that important aspects of these roles are better understood in the vocabulary of identification, interpretation, and community. I must reinind you of what I said at the outset, that I take interaction between both polarities to provide a key to a proper understanding of law. So iny stressing the pole that $I$ did is purely reactive, to right an imbalance in present day jurisprudence that Dworkin's theory inainly creates. My second and related observation is this: The ternis I used to characterize one pole-identification, community, and interpretation - are likely to sound to many ears as friendly terins, whereas the other three-distance, orgamization, and strategic communication-will sound as hostile ones. The tone with which I have used these teruns may indeed have contributed to this impression. I

24. For a compelling expression of a vision of law and of the judicial role that accentuates their coerciveness see Cover, The Supreme Court, 1982 Term-Foreword: Nomos and Narrative, 97 HARV. L. REV. 4 (1983), and Violence and the Word, 95 YALE L.J. 1601 (1986). 
therefore must make clear that it is not part of my overt or hidden agenda to endorse the former pole and condemn the latter one. To be sure, there is a great temptation to envision utopias conceived exclusively in terms of the friendly categories. ${ }^{25}$ But short of utopia, we must contend with both poles. There is need and value in distance as well as identification, organization as well as community, communciation as well as interpretation, although of course there is room for much disagreement concerning the desirable proportions between the two sets in our imperfect, non-utopian world. My main point is a much more limited one, and it is imdependent of our attitude to the two contrasting poles of social life. It can be put-somewhat tendentiously-this way: That we should be wary of a fable that likens the operation of the judicial system to an exercise in the composition of a chain novel, ${ }^{26}$ and of a legal theory that considers literary criticism as an adequate model for the legal enterprise. It is quite a strange novel that has as its dramatic punchline the execution of some of its intended readers. And this prospect, while no doubt concentrating these readers' minds, may put a strain on their interpretive skills that is quite unfamiliar in hterary circles.

25. Such a temptation is one of the themes in Gabel and Kennedy, Roll Over Beethoven, 36 STAN. L. REV. 1 (1984).

26. See Dworkin, supra, note 4 , at 228-38. 